\title{
Implikasi Perubahan Undang-Undang Dasar 1945 Terhadap Sistem Ketatanegaraan Indonesia
}

\author{
ZulqadriAnand \\ Mahasiswa Bagian HTN, angkatan 2009
}

\begin{abstract}
Abstrak
Tulisan ini bertujuan untuk mengkaji tentang implikasi perubahan UndangUndang Dasar 1945 terhadap sistem ketatanegaraan.Penulisan bersifat normatif dengan menempatkan bahan hukum primer dan sekunder sebagai rujukan. Hasil pengkajian menunjukan bahwa terdapat implikasi yang nyata dalam sistem ketatanegaraan berupa perubahan di berbagai bidang kehidupan bernegara. Perubahan tersebut secara positif mengarah kepada pembentukan negara Indonesia yang lebih demokratis.
\end{abstract}

Kata kunci : Implikasi, perubahan UUD, dan sistem ketatanegaraan.

\section{Pendahuluan}

Adanya sebuah konstitusi merupakan pemikiran yang telah lama berkembang. Hal ini menghendaki adanya ide terhadap pembatasan kekuasaan pemerintah. Pembatasan tersebut agar dapat terlaksana dengan baik dan mendapatkan sebuah kepastian maka harus berdasarkan oleh hukum. Hakikat konstitusi itu sendiri tidak lain adalah pembatasan terhadap kekuasaan pemerintahan di satu pihak dan jaminan terhadap hak-hak warga negara maupun setiap penduduk dipihak lain. Hak-hak ini mencakup hak-hak dasar seperti hak untuk hidup, mempunyai milik, kesejahteraan (health), dan kebebasan.

Menurut Mc Ilwan, ${ }^{1}$ ada dua unsur fundamental dari konstitusi, yaitu batas-batas hukum terhadap kekuasaan yang sewenang-wenang dan pertanggung jawaban politik

1 Dikutipdari Budiman N.P.D Sinaga, Hukum Tata Negara, PerubahanUndangUndang Dasar, Jakarta PT Tata Nusa,2009, hlm. 59. sepenuhnya dari pemerintah kepada yang diperintah. Sebuah negara atau sistem pemerintahan apapun harus didirikan berdasarkan hukum, ketika kekuasaan dalam negara dilaksanakan mesti disesuaikan dengan ketentuan dan prosedur hukum. Struktur lembaga-lembaga pemerintah harus menjamin bahwa kekuasaan yang diberikan dapat dilaksanakan dengan baik guna mencapai tujuan bersama yakni menuju kesejahteraan bersama. Disini gagasan sebuah konstitusi mengandung arti bahwa penguasa perlu dibatasi kekuasaannya dan karena itu kekuasaannya harus diperinci secara tegas. Terdapat penekanan bahwa pemegang kekuasaan hanya mempunyai kekuasaan yang sudah dirinci. Tidak ada kekuasaan penguasa di luar kekuasaan yang sudah dirinci.

Harus diakui bahwa konstitusi adalah sebagai kesepakatan politik yang terdapat berbagai macam cara pandang didalamnya. Sebagai produk dari manusia konstitusi juga memiliki beberapa kekurangan baik disebabkan oleh substansi yang ada 
di dalamnnya ataupun disebabkan oleh implementasinya. Bertolak dari kekurangan yang ada maka amandemen terhadap substansi yang terdapat di dalam UUD 1945 adalah menjadi sebuah tuntutan mutlak. Menurut I Gde Pantja Astawa paling tidak ada tiga alasan utama yang dapat diidentifikasikan sehingga UUD 1945 perlu diubah, yaitu: ${ }^{2}$

1. Berangkat dari pemaknaan reformasi yang antara lain diartikan sebagai constitutional reform dan cultural reform sehingga berbicara reformasi berati mereformasi atau memperbaharui konstitusi atau Undang-undang dasar dan cultur.

2. Didasarkan pada pandangan yang menilai UUD 1945 memiliki watak yang sentralistik, terutama membuka peluang kearah sentralisasi kekuasaan pada eksekutif atau presiden, sehingga siapapun yang menjadi presiden akan mengulangi kecenderungan yang sama yang dinilai bertindak otoriter. Maka dari itu untuk menghindari kesalahan yang sama, maka sumber penyebabnya harus diperbaiki, dan perubahan terhadap konstitusi merupakan sebuah keniscayaan.

3. Adanya pendapat dengan menunjuk pada salah seorang arsitek yang merancang bangunan UUD 1945 yaitu Soepomo yang dinilai menularkan pikiran-pikiran fasis melalui paham integralistiknya.

Berdasarkan uraian yang disampaikan jelas terlihat bahwa pendapat untuk diadakannya

2 I GdePantjaAstawa, Beberapacatatan tentangPerubahan UUD 1945, jurnal Demokrasi dan HAM, Vol. 1, No.4, September-November 2001, hlm.33. amandemen terhadap Undangundang dasar 1945 sangat masuk akal dan harus direalisasikan dengan sesegera mungkin. Berdasarkan arus gerakan yang menginginkan adanya perubahan maka akhirnya Undangundang dasar 1945 secara konstitusional berhasil diamandemen. Tanggal 19 Oktober 1999 MPR mengeluarkan perubahan pertama UUD 1945. dalam kesempatan ini MPR telah mengubah sembilan pasal dalam UUD 1945. Mengingat UUD 1945 hanya terdiri dari 37 pasal, maka perubahan ini dapat dikatakan cukup banyak karena mencakup hampir sperempat bagian.

Meskipun demikian, MPR masih belum merasa cukup sehingga mengeluarkan ketetapan MPR No. IX/MPR/1999 Tentang Penugasan Badan Pekerja Majelis Permusyawaratan Republik Indonesia untuk melanjutkan perubahan Undang-undang dasar Negara Republik Indonesia Tahun 1945. Bagir Manan terhadap perubahan ini mengatakan telah terdapat beberapa tindakan seperti berikut ini: perubahan terhadap isi (substansi) ketentuan yang sudah ada; penambahan ketentuan yang sudah ada; pengembangan materi muatan yang sudah ada menjadi bab baru; penambahan sama sekali baru; pengahapusan ketentuan yang sudah ada; memasukkan dan memindahkan beberapa isi penjelasan ke dalam Batang tubuh; perubahan struktur UUD 1945 dan menghapus penjelasan sebagai bagian dari UUD $1945^{3}$. Amandemen terhadap UUD 1945 memang dimungkinkan untuk

\footnotetext{
3 Bagir Manan, DPR, DPD, dan MPR Dalam UUD 1945 Baru, Yogyakarta: FH UII Press 2003, hlm. 1.
} 
dilakukan karena telah diatur dalam pasal 37.

Menurut Sri soemantri didalam pasal 37 mengandung tiga norma, yaitu: ${ }^{4}$.

1. bahwa wewenang untuk mengubah Undang-Undang Dasar pada MPR sebagai Lembaga Tertinggi Negara;

2. bahwa untuk mengubah untuk mengubah Undang-undang Dasar kuorum yang harus dipenuhi sekurang-kurangnya adalah $2 / 3$ dari seluruh jumlah anggota MPR; dan

3. bahwa putusan tentang perubahan Undang-Undang Dasar adalah sah apabila disetujui oleh sekurangkurangnya 2/3 dari anggota MPR yang hadir.

Dalam ketentuan diatas tidak ditemukan ketentuan yang secara sengaja mengatur tentang pembatasan perubahan Undangundang Dasar. Maka dari itu untuk menghindari adanya perubahan terhadap kesepakatan luhur bangsa, Fraksi-fraksi MPR RI 1999 sebagaimana terdapat dalam lampiran ketetapan MPR No. IX/MPR/1999 tentang Penugasan Badan Pekerja Majelis Permusyawaratan Republik Indonesia untuk melanjutkan perubahan Undang-Undang Dasar Negara Kesatuan Republik Indonesia untuk melanjutkan Perubahan Undang-Undang dasar Negara Kesatuan Republik Indonesia Tahun 1945, bersepakat bahwa arah dan cara-cara perubahan UUD 1945 adalah :

1. tidak mengubah pembukaan UUD 1945

4 Sri Seomantri, Prosedur dan sistem perubahan konstitusi, Bandung: Alumni, 1984, hlm.65.
2. tetap mempertahankan Negara Kesatuan Republik Indonesia

3. mempertegas sistem pemerintah presidensial

4. penjelasan UUD

ditiadakan serta hal-hal normatif dalam penjelasan UUD 1945 harus dimasukkan ke dalam pasal-pasal yang ada dalam batang tubuh UUD 1945; dan

5. perubahan dilakukan dengan cara "adendum"

Dalam hal ini Mahfud MD berpendapat keputusan untuk tidak mengubah pembukaan UUD 1945 merupakan keputusan yang tepat, baik secara filosofis maupun secara politis, dalam hidup bernegara bagi bangsa Indonesia. Secara filosofis, pembukaan UUD 1945 yang di dalamnya terdapat pancasila merupakan modus vivendi (kesepakatan luhur) bangsa Indonesia untuk hidup bersama dalam ikatan satu bangsa yang majemuk. Ia juga dapat disebut sebagai tanda kelahiran (akte) karena sebagai modus vivendi didalamnya juga memuat pernyataan kemerdekaan (proklamasi) serta identitas diri dan pijakan melangkah untuk mencapai cita-cita bangsa dan tujuan Negara. Jika pembukaan diubah maka Indonesia yang ada bukanlah Indonesia yang aktenya dikeluarkan pada tanggal 17 Agustus 1945 melainkan Indonesia yang lain lagi. Secara politik, langkah yang diambil oleh MPR adalah benar adanya. Sebab gerakan reformasi menuntut adanya pembatasan kekuasaan pemerintah agar tidak sewenang-wenang. Untuk membenahi sistem yang ada diperlukan adanya perubahan terhadap isi dari UUD 1945 tanpa harus mempersoalkan pembukaan karena otoriterisme muncul bukan 
bersumber dari pembukaan melainkan bersumber dari pasalpasal UUD tersebut. ${ }^{5}$ Telah banyak perubahan yang terjadi pasca amandemen UUD 1945, diantaranya di bidang hukum, politik dan sebagainya. Lalu apakah implikasi perubahan tersebut terhadap sistem ketatanegaraan Indonesia?

\section{Pembahasan}

\section{Penegasan Negara Hukum}

Konsepsi manusia tentang negara hukum sudah lahir dan berkembang dalam situasi kesejarahan. Secara eksplisit, gagasan negara hukum telah dikemukakan oleh plato, ketika ia mengintroduksi konsep Nomoi. Dikemukakan bahwa penyelenggaraan negara yang baik ialah yang didasarkan pada pengaturan (hukum) yang baik. Perumusan negara hukum ini tidak terlepas dari falsafah dan sosio politik yang melatarbelakanginya terutama menempatkan individu atau warga negara sebagai primus interpares dalam kehidupan bernegara. Oleh karena itu, unsur pembatasan kekuasaan negara untuk melindungi hak-hak individu menempati posisi yang signifikan. Konsepsi negara hukum semakin menguat sesuai dengan adagium Lord Acton yaitu bahwa manusia yang mempunyai kekuasaan cenderung untuk menyalah gunakan kekuasaan yang dimilikinya, dan kekuasaan yang absolute pasti akan disalah gunakan.

Perjalanan bangsa ini telah membuktikan bahwa kekuasaan yang pernah ada dan tidak berlandaskan

5 Moh.Mahfud MD, Perdebatan Hukum Tata Negara PascaAmandemen Konstitusi, Jakarta: RajawaliPers, 2010, hlm.2. atas hukum maka akan bersifat otoriter. Rezim orde lama dengan karakteristik demokrasi terpimpin telah membawa kekuasaan menuju sentalistik. Setiap kebijakan umum diperoleh berdasarkan kehendak tertentu dengan tidak memperhatikan aspek yang ada ditengah masyarakat. Model kepemimpinan seperti ini tidak mengedepankan prinsip demokrasi bahkan akan menimbulkan disintegrasi bangsa karena masyarakat merasa tidak memiliki peran dalam membangun bangsa.

Hal yang sama juga terjadi di era kepemimpinan orde baru. Model kepemimpinan yang di pergunakan selalu berusaha menyatukan berbagai elemen yang ada dengan tidak memperhatikan segala aspirasi yang ada sehingga menimbulkan pemasungan terhadap hak-hak konstitusional warga negara. Unsurunsur kekuasaan tidak berjalan sebagaimana mestinya sehingga kekuasaan eksekutif berkuasa lebih dominan (executive heavy). Tentu saja hal ini bertentangan konsep demokrasi konstitusional dan negara hukum yang di adopsi oleh bangsa Indonesia bahwa pemerintah yang demokratis adalah terbatas kekuasaanya dan tidak dibenarkan bertindak sewenang-wenang.

Disebabkan oleh kekuasaan yang tak terbatas dan karena tidak secara konsisten menjadikan hukum sebagai dasar, maka pemerintahan yang ada di negeri ini penuhi oleh praktek korupsi kolusi dan nepotisme. Jika kita telusuri lebih dalam, maka tujuan utama munculnya gerakan reformasi tahun 1998, yang merupakan "jalan pintas" bagi penggantian pemerintahan, adalah untuk memberantas korupsi yang sudah menjangkit disegala lini 
kehidupan masyarakat Indonesia. Setiap kebijakan disegala bidang (politik, ekonomi, buday, hankam dan lainnya) selalu berorientasi kepada upaya untuk memerangi budaya korupsi. Fakta yang terjadi menunjukan bahwa krisis multidimensi yang ada di Negara ini terjadi karena "virus" korupsi. Moralitas bangsa sudah hancur karena praktek tersebut. Birokrasibirokrasi yang ada dipenuhi dengan sanak family, dan teman sejawat dengan tidak menjadikan kualitas seseorang sebagai prioritas utamanya. Aparat penegak hukum yang diharapkan dapat mengurangi kemudian dapat menghilangkan praktek-praktek kotor tersebut ternyata tidak berjalan sebagaimana yang diharapkan bersama.

Hal ini disebabkan karena spectrum politik nasional dikuasai oleh sebuah partai hegemonic dan kekuatan militer dengan Dwifungsi ABRI-nya. Padahal menurut Helmes, salah seorang ahli hukum Belanda, mengatakan hukum itu adalah bukan kata-kata yang tertulis dengan indah, akan tetapi hukum adalah apa yang dilakukan oleh aparat penegak hukum itu sendiri. Selain itu substansi hukum juga lebih bertendensi menciptakan keadaan sebagaimana yang diinginkan oleh rezim tersebut.

Mahfud MD dalam hal ini berpendapat bahwa hukum yang ada dalam rezim orde baru bersifat ortodoks dan konservatif, yang ditandai oleh hal-hal berikut ini: ${ }^{6}$

\footnotetext{
6 Moh.Mahfud MD, Perdebatan Hukum Tata Negara PascaAmandemen Konstitusi, Jakarta: RajawaliPers, 2010, hlm.179.

${ }^{8}$ Terpetik dari J.B.J.M. ten Berge, Besturen Door De Overheid, W.E.J. Tjeenk Willink,Deventer,1966, hlm. 34-38
}

1. proses pembuatannya sangat sentralistik, semuanya bersumber dan harus menerima materi yang disiapkan oleh pihak eksekutif

2. sifat isinya adalah posivistikinstrumentalistik, hukum dijadikan alat untuk membenarkan kehendakkehendak sepihak lembaga eksekutif

3. cakupan isinya openinterpretatif, sehingga dapat ditafsirkan sesuai dengan kepentingan politiknya.

4. Implementasinya mengutamakan kebijakan sehingga banyak hukum yang dilanggar hanya dengan kebijakan.

5. Implementasinya juga menekankan pada perlindungan korps, sehingga ketika ada anggota korps yang melanggar hukum maka akan segera dilindungi agar tidak mencemarkan nama korpsnya.

Dalam pasal 1 ayat ( 3 ) UUD 1945 dinyatakan: “ Negara Indonesia adalah negara Hukum." Ketentuan ini merupakan hasil dari Perubahan Ketiga UUD 1945. Sebelum Perubahan Ketiga tidak ada ketentuan yang secara tegas menyatakan Indonesia sebagai negara hukum sehingga sering menimbulkan keraguan. Menurut Sudargo Gautama dalam suatu negara hukum, terdapat pembatasan kekuasaan negara terhadap perorangan. Tidak dibolehkan tindakan sewenang-wenang dari penguasa kepada warga negara. Implikasi dari penegasan tersebut adalah kekuasaan yang terbatas dan dibentuknya lembaga yang berfungsi melakukan penegakan hukum.

Penegasan terhadap negara hukum, juga memiliki implikasi 
terhadap terbentuknya sebuah lembaga Negara yang berfungsi sebagai pengawal tegaknya hukum. Sesuai dengan konsep negara hukum yang dikemukakan oleh J.B.J.M ten Berge bahwa setiap negara hukum diperlukan sebuah pengawasan oleh lembaga dan hakim yang merdeka ${ }^{7}$. Perkembangan yang lebih maju dalam politik hukum kekuasaan kehakiman ini kemudian dituangkan juga dalam amandemen UUD 1945. Pada perubahan (amandemen) ketiga, tahun 2001, pasal 24 ayat (2) UUD 1945 menyebutkan bahwa kekuasaan kehakiman di Indonesia dilakukan oleh Mahkamah Agung dan Mahkamah Konstitusi dengan kompetensi yang berbeda.

$\begin{array}{cr}\text { Mahkamah } & \text { Konstitusi } \\ \text { dimunculkan sebagai lembaga }\end{array}$

Negara dengan hak melakukan uju materi (judicial review) UU terhadap UUD. Mahkamah Konstitusi juga mempunyai tugas lain yaitu, memutus pendapat DPR bahwa Presiden/wakil presiden tidak lagi memenuhi syarat, memutus pendapat DPR bahwa Presiden dan atau wakil Presiden telah melanggar hal-hal tertentu yang telah ditentukan didalam UUD, memutus sengketa kewenangan antar lembaga negara yang kewenangannya diberikan oleh UUD, memutus pembubaran partai politik dan memutus sengketa hasil pemilu.

Mengenai judicial review, hal ini tidak bisa dilepaskan dari sejarah Jhon Marshall yang membatalkan Judiciary Act 1789 secara sepihak dengan alasan act tersebut bertentangan dengan konstitusi Amerika. Dalam hal ini ada 4 alasan mengapa proses judicial review dibenarkan secara hukum; a. hakim bersumpah untuk menjunjung tinggi konstitusi, sehingga jika ada peraturan yang bertentangan dengan konstitusi maka perlu dilakukan uju materi.

b. Konstitusi adalah the supreme law of the land sehingga harus ada pengujian terhadap peraturan yang di bawahnya agar the supreme law tersebut tidak dilangkahi isinya.

c. Hakim tidak boleh menolak perkara, sehingga kalau ada yang mengajukan permintaan judicial review harus dipenuhi.

d. Pemahaman bahwa hukum adalah produk politik. Karena hukum adalah produk politik, maka harus ada mekanisme pengujian agar isi maupun prosedur pembuatannya benar secara hukum.

Politik hukum yang mendasari pembentukan Mahkamah Konstitusi adalah menjaga agar tidak ada Undang-undang yang bertentangan dengan UUD sebagai kaidah penuntun hukum dibawahnya, dan kalaupun ada Mahkamah Konstitusi dapat membatalkannya. Itulah sebabnya, sering dikatakan bahwa Mahkamah Konstitusi sebagai pengawal konstitusi dan penfsir tunggal konstitusi. Dalam hal pengambilan setiap putusan Mahkamah Konstitusi hendaknya selalu berhati-hati. Hal ini dikarenakan selain sebagai lembaga peradilan hukum, tak jarang banyak pihak yang menganggap lembaga ini sebagai lembagai peradilan politik. Dalam hal penyebutan ini penulis sependapat karena Mahkamah Konstitusi memang mengurusi halhal yang bersifat politik terutama dalam hal impeachment. Dalam proses pemakzulan presiden dan atau wakil presiden di dalam Undang- 
undang Dasar diatur dalam dua mekanisme antara impeachment dan forum previlegiatum ${ }^{8}$.

Dengan impeachment

dimaksudkan bahwa presiden dijatuhkan oleh lembaga politik yang mencerminkan wakil seluruh rakyat, melalui penilaian dan keputusan politik dengan syarat-syarat dan mekanisme yang ketat. Sedangkan forum previlegiatum adalah penjatuhan presiden dan atau wakil presiden melalui pengadilan khusus ketatanegaraan yang dasarnya adalah pelanggaran hukum berat yang ditentukan di dalam konstitusi dengan putusan hukum pula. Hal lain yang selalu menjadi perdebatan adalah batasan-batasan dalam pengambilan sebuah putusan. Hal ini dimaksudkan karena yang menjadi objek dari pada penyelesaian di Mahkamah Konstitusi dalam hal judicial review adalah Undangundang sebagai produk dari lembaga legislatif. Dalam hal ini Mahkamah Konstitusi tidak boleh membuat putusan yang bersifat mengatur. Tugas Mahkamah Konstitusi dalam hal ini hanyalah menyatakan apakah UU tersebut bertentangan dengan UUD 1945. Betapapun Mahkamah Konstitusi mempunyai pemikiran untuk mengatur sebagai alternatif UU yang telah dibatalkan, maka hal itu tidak boleh dilakukan, karena yang mempunyai peran mengatur adalah legislatif. Mengenai hal ini penulis berpendapat berbeda.

$$
\text { Bagi penulis, sebuah }
$$

permohonan yang diajukan kepada Mahkamah Konstitusi diharapkan ada sebuah penyelesaian secara hukum sehingga dapat menyelesaikan masalah yang ada. Jika hal tersebut tidak dilakukan oleh

\footnotetext{
${ }^{8}$ Lihat Undang-Undang Dasar 1945, Pasal 7B
}

mahkamah konstitusi maka masalah akan selalu ada sebelum dilakukanya revisi undang-undang oleh lembaga legislatif. Padahal kita ketahui bersama proses pembentukan Undang-undang di lembaga legislatif membutuhkan waktu yang cukup lama. Selain itu, terkadang pasalpasal yang dimohonkan menjadi jantung dari pada Undang-undang, maka dari itu penyelesaiaannya harus dilakukan sesegera mungkin sehingga tidak berdampak besar terhadap psal-pasal lainnya.

Bagi penulis point penting dari penegasan bahwa Indonesia adalah negara hukum adalah proses penyelesaian setiap masalah selalu melalui prosedur hukum, tanpa lagi dapat diselesaikan hanya melalui prosedur politik saja.

\section{Pemilihan Umum Secara Langsung \\ Sebelum \\ terjadinya} amandemen UUD 1945, sistem perpolitikan di Indonesia didominasi oleh kekuatan tertentu dan cenderung tertutup. Masyarakat tidak memiliki bargaining position dalam menentukan kebijakan yang diambil. Tidak adanya partisipasi publik menjadikan kekuasaan yang ada sulit untuk di lakukan pengawasan dan cenderung untuk bersifat sewenangwenang. Tertutupnya rekrutmen para penyelenggara negara ini membuka peluang untuk terjadinya hegemoni kekuasaan. Padahal Moh. Kusnardi dan Harmaily Ibrahim, dalam paham kedaulatan rakyat (democracy), mengatakan rakyatlah yang dianggap sebagai pemilik dan pemegang kekuasan tertinggi dalam suatu negara. Rakyatlah yang menetukan corak dan cara pemerintahan diselenggarakan. Rakyatlah yang menentukan tujuan 
yang hendak dicapai oleh negara dan pemerintahannya itu.

Namun dalam kenyataannya memang hal tersebut sangat sulit untuk dilakukan. Hal itu dikarenakan tingkat kehidupan yang berkembang sangat kompleks dan dinamis, dengan tingkat kecerdasan warga yang tidak merata dan dengan tingkat spesialisasi antarsektor pekerjaaan yang juga bebeda. Kompleksitas tersebut menghendaki bahwa kedaulatan rakyat itu dilaksanakan dengan melalui sistem perwakilan (representation).

Dalam praktiknya proses yang dirasakan paling ideal adalah dengan melalui proses pemilihan umum. Jimly asshiddiqie berpendapat, paling tidak ada 4 hal tujuan dilaksanakannya pemilihan umum, yaitu

a. untuk memungkinkan terjadinya peralihan kepemimpinan pemerintahan secara tertib dan damai.

b. Untuk memungkinkan tejadinya pergantian pejabat yang akan mewakili kepentingan rakyat dilembaga perwakilan.

c. Untuk melaksanakan prinsip kedaulatan rakyat;

d. Untuk melaksanakan prinsip hak-hak asasi warga negara ${ }^{11}$.

Proses pemilihan umum secara langsung kita rasakan pasca amandemen UUD 1945. pilihan politik pada saat itu menghendaki untuk diadakannya pemilihan umum secara langsung. Konstitusi kita telah mengatur hal ini di dalam pasal 1 ayat 2 UUD 1945 yang berbunyi “ kedaulatan adalah di tangan rakyat dan dilaksanakan menurut UUD". Apabila kita mempergunakan interpretasi gramatikal dalam membaca Undang-undang ini maka jelas bahwa pemilihan umum harus dilaksnakan secara langsung oleh rakyat.

Secara umum ada 2 alasan diadakannya pemilihan secara langsung. Pertama, pemilihan langsung dianggap lebih membuka peluang bagi tampilnya para penyelenggara negara yang sesuai dengan kehendak rakyat sendiri. Alasan kedua adalah untuk menjaga stabilitas pemerintahan agar tidak mudah dijatuhkan ditengah jalan.

Dengan adanya pemilihan secara langsung, legitimasi yang dimiliki akan sangat kuat karena harus mempunyai dukungan yang besar dari rakyat sebagai pemegang kekuasaan tertinggi. Fakta yang ada di lapangan membuktikan sebelum beralihnya kepada pemilihan langsung oleh rakyat, politik transaksional banyak mewarnai pengisian jabatan di negeri ini. Selain itu terkadang kebijakan yang diambil oleh lembaga perwakilan rakyat tidak berbanding lurus dengan apa yang menjadi keinginan rakyat secara mayoritas.

Pemilihan politik secara langsung memang baik untuk demokrasi di negeri ini. Namun, kita juga harus hati-hati dalam menyikapinya agar demokrasi dapat selalu menjaga integrasi bangsa dan bukan sebaliknya mendatangkan disintegrasi bangsa. Dengan adanya pemilihan secara langsung maka akan cenderung memenangkan calon yang berasal dari etnis dan agama secara mayoritas. Hal tersebut akan membuat etnis dan agama yang memiliki suara minoritas menjadi apatis terhadap hasil yang telah dicapai.

Selain itu dengan adanya pemilihan politik secara langsung juga akan memunculkan calon yang tidak berkualitas. Hal ini didasarkan 
seorang calon dapat mencalonkan diri melalui jalur independent yang telah mendapatkan kekuatan hukum berdasarkan putusan Mahkamah Konstitusi. Calon tersebut hanya mengutamakan kharismatik yang juga didukung oleh kemampuan financial sehingga kapabilitas dan juga moralitas seorang calon menjadi dikesampingkan.

Namun pendapat yang demikian itu tidak boleh kita jadikan dasar untuk mengembalikan kepada sistem lama, karena apapun yang terjadi itulah konsekuensi logis dari berlakunya prinsip demokrasi. Ketika prinsip ini yang menjadi pilihan kita bersama, kita tidak bisa menjadi apatis lalu mengolok-olok pilihan rakyat berdasarkan tingkat kesadaran politik dan pendidikan masing-masing.

Hal yang dapat kita lakukan agar demokrasi berjalan sesuai dengan harapan adalah dengan memberikan pendidikan politik kepada warga masyarakat yang mempunyai hak pilih untuk dapat menggunakannya sesuai dengan hati nurani. Selain itu proses selektif diinternal parpol juga harus diperkuat agar nantinya tidak menghasilkan politisi-politisi tanpa visi dan menutup peluang terjadinya rekrutmen politik yang tertutup sehingga dapat mencegah terjadinya politik transaksional.

\section{Penguatan sistem checks and balances}

Ketika arus gerakan reformasi berhasil menumbangkan sakralisasi UUD 1945, banyak pula tuntutan dari arus bawah untuk memperbaiki UUD agar ia mampu membangun sitem politik dan ketatanegaraan yang demokratis. Gagasan ini memiliki urgensi yang sangat kuat, mengingat dalam tiga periode sistem politik ternyata di Indonesia tak pernah lahir sistem politik yang demokratis sehingga selalu menimbulkan korupsi dalam berbagai bidang kehidupan.

Ide yang muncul ketika itu adanya sistem dan mekanisme chekcs and balances (saling kontrol dan mengawasi). Check and balances adalah sebuah mekanisme untuk selalu melakukan pengawasan dan penyeimbangan oleh kekuasaan negara yang ada sesuai dengan fungsi yang diamanatkan oleh konstitusi. Dalam hal kekuasaan negara, penulis menggunakan teori yang pernah dikemukaan oleh montesque dengan trias politikanya yang membagi kekuasaan kedalam 3 bidang, yaitu;

a. kekuasaan eksekutif, pelaksana Undang-undang

b. kekuasaan legislatif, pembuat Undang-undang

c. kekuasaan yudikatif, pelaksana fungsi peradilan

Dalam hal pembuatan Undangundang, sebelum dilakukannya amandemen terhadap konstitusi seluruh mekanisme didominasi oleh eksekutif, baik proses inisiatif maupun proses pengesahannya. Pada saat itu hampir dipastikan tidak ada RUU yang datangnya dari DPR yang notabennya sebagai representasi rakyat. Bahkan pada masa orde baru, RUU yang semula berasal dari Presiden pun pernah ditolak untuk disahkan oleh Presiden sendiri setelah disetujui oleh DPR melalui pembahasan bersama pemerintah selama tak kurang dari 8 bulan.

Maka dengan adanya amandemen terhadap konstitusi, fungsi dan peran eksekutif sebagai pembuat, pelaksana, dan penafsir 
sebuah Undang-undang direduksi dan diberikan kepada lembaga lainnya untuk melaksanakan fungsi pengawasan. Dalam hal pembentukan sebuah Undangundang DPR memiliki peranaan yang sangat besar. Sebuah rancangan yang diajukan oleh pemerintah harus melalui pembahasan bersama di DPR untuk mendapat persetujuan bersama. Apabila tidak terjadi sebuah kesepakatan, maka rancangan undang-undang yang di ajukan oleh pemerintah tadi tidak boleh diajukan kembali pada sidang masa itu.

Jika pada masa orde baru presiden dpat membatalkan RUU yang telah disetujui oleh DPR, maka hal tersebut sangat sulit untuk dilakukan untuk sekarang ini. Dalam hal ini, pasal 20 ayat 5 UUD 1945 menutup celah untuk terjadinya kesalahan seperti dulu. Ketentuan yang terdapat dalam pasal 20 adalah apabila sebuah rancangan undangundang yang telah disetujui bersama tidak disahkan oleh presiden, maka setelah 30 hari semenjak rancangan tersebut disetujui, maka rancangan tersebut menjadi sah dan wajib untuk diundangkan. Hal lainnya adalah Anggota DPR memiliki hak untuk mengajukan rancangan Undangundang sama seperti hak yang dimiliki oleh presiden (pasal 5 dan pasal 21$)^{9}$.

Selain memiliki fungsi legislasi pembuatan undang-undang, DPR juga memiliki fungsi melakukan pengawasan (kontrol) . Hal ini perlu ada mengingat kekuasaan yang dimiliki oleh kekuasaan eksekutif sangat besar dan juga bertendensi untuk terjadi penyalaahgunaan kekuasaan. Presthus membagi 2 tugas negara yang dijalankan oleh

\footnotetext{
${ }^{9}$ LihatUndang-undangDasar 1945, pasal 20
}

pemerintah, yaitu (a) policy making, penetuan haluan; dan (b) task executing, yaitu pelaksanaan tugas menurut haluan yang telah ditetapkan bersama.

DPR sebagai lembaga perwakilan rakyat, dapat memintakan pertanggung jawaban atas setiap kebijakan yang telah diambil oleh pemerintah. Ketika kebijakan tersebut dirasakan ada ${ }^{10}$ prosedur yang dilanggar, atau isi dari kebijakan tersebut tidak sesuai dengan harapan masyarakat secara rasional, maka DPR dapat menggunakan hak-haknya sebagai bentuk pengawasan yang dilakukan (interplasi, angket, dan menyatakan pendapat).

Dalam kenyataannya sekarang, DPR telah melakukan fungsi pengawasan yang cukup baik. Setiap kebijakan pemerintah yang menyangkut hajat hidup orang banyak, selalu mendapatkan perhatian khusus dari DPR. Namun, terkadang hal tersebut tidak berujung terhadap apa yang menjadi kehendak rakyat secara meyoritas. Bahkan tak jarang, hal-hal tersebut dijadikan manuver politik oleh para elit partai politik guna meningkatkan Bargaining positionnya terhadap presiden yang tentu saja bermuara kepada kepentingan politik pragmatis.

Selain itu kekuasaan kehakiman juga dapat melakukan proses check balances. Proses ini biasanya dikenal dengan istilah judicial review. Harus diakui bahwa hukum adalah sebuah produk politik, yang tidak menutup kemungkinan dalam proses pembuatannya "diselipi" oleh kepentingan-

\footnotetext{
${ }^{13}$ Lihat Undang-Undang Dasar 1945, Pasal 5.
} 
kepentingan politik pragmatis. Ketika produk politik tersebut diimplementasikan kedalam kehidupan masyarakat, tak jarang mendapatkan pertentangan karena substansi hukum itu sendiri. Maka dari itu, lembaga kekuasaan kehakiman memiliki kewenangan untuk melakukan judicial review terhadap produk politik tersebut (pasal 24). Hal ini pun sesuai dengan prinsip negara hukum, bahwa harus ada pengawalan terhadap hak-hak konstitusinal warga negara termasuk terhadap hukum itu sendiri. Demokrasi tanpa hukum dapat menjadi anarki, hukum tanpa demokrasi maka akan kehilangan makna.

\section{Penutup}

\section{Kesimpulan}

Setelah melalui perjuangan panjang, pada akhirnya bangsa Indonesia dapat melakukan perubahan (amandemen) atas UUD 1945. kemajuan besar dalam sistem ketatanegaraan telah dapat dilihat dari hasil perubahan tersebut, terutama dengan adanya penegasan bahwa indonesia adalah negara hukum, pemilihan umum secara langsung, serta menguatnya format dan mekanisme cheks and balances. Dengan adanya amandemen UUD 1945 diharapkan dapat membawa bangsa kearah yang lebih baik, sesuai dengan cita-cita kita bersama.

\section{Saran}

Diperlukan sebuah perubahan ke-5 terhadap Undang-undang Dasar 1945 untuk dapat memperbaiki isi yang belum secara utuh dilaksanakan dan untuk memberikan energi positif dalam sistem ketatanegaraan.

\section{DAFTAR PUSTAKA}

Asshiddiqie, Jimly. 2009. Pengantar Ilmu Hukum Tata Negara. Jakarta: PT RajaGrafindo Persada.

Sinaga Budiman N.P.D. 2009. Hukum Tata Negara, Perubahan Undang-Undang Dasar. Jakarta: PT Tata Nusa.

Mahfud MD, Moh. 2009. Konstitusi Dan Hukum Dalam Kontroversi Isu. Jakarta: Rajawali Pers. -2010. Perdebatan Hukum Tata Negara Pasca Amandemen Konstitusi. Jakarta: PT RajaGrafindo Persada.

$\begin{array}{ll} & \text { Politik Hukum, Menegakkan } \\ & \text { Konstitusi. Jakarta: PT } \\ & \text { RajaGrafindo. } \\ \text { HR 2006. Hukum } & \text { Ridwan 2006. Negara. } \\ & \text { Administrasi } \\ \text { Jakarta: PT RajaGrafindo. }\end{array}$

